\title{
Development of palladium catalysts modified by ruthenium and molybdenum as anode in direct ethanol fuel cell
}

\author{
Yonis Fornazier Filho ${ }^{1}$ - Ana Caroliny Carvalho da $\mathrm{Cruz}^{1} \cdot$ Rolando Pedicini $^{2} \cdot$ José Ricardo Cezar Salgado $^{3}$. \\ Priscilla Paiva Luz ${ }^{1} \cdot J^{1}$ sosimar Ribeiro ${ }^{1}$ (i)
}

Received: 2 September 2020 / Accepted: 30 December 2020 / Published online: 2 February 2021

(c) The Author(s) 2021

\begin{abstract}
Physical and electrochemical properties of $\mathrm{Pd}$ catalysts combined with $\mathrm{Ru}$ and Mo on carbon support were investigated. To this end, $\mathrm{Pd}, \mathrm{Pd}_{1.3} \mathrm{Ru}_{1.0}, \mathrm{Pd}_{3.2} \mathrm{Ru}_{1.3} \mathrm{Mo}_{1.0}$ and $\mathrm{Pd}_{1.5} \mathrm{Ru}_{0.8} \mathrm{Mo}_{1.0}$ were synthesized on Carbon Vulcan $\mathrm{XC72}$ support by the method of thermal decomposition of polymeric precursors and then physically and electrochemically characterized. The highest reaction yields are obtained for $\mathrm{Pd}_{3.2} \mathrm{Ru}_{1.3} \mathrm{Mo}_{1.0} / \mathrm{C}$ and $\mathrm{Pd}_{1.5} \mathrm{Ru}_{0.8} \mathrm{Mo}_{1.0} / \mathrm{C}$ and, as demonstrated by thermal analysis, they also show the smallest metal/carbon ratio compared the other catalysts. XRD (X-ray Diffraction) and Raman analyses show the presence of $\mathrm{PdO}$ and $\mathrm{RuO}_{2}$ for the $\mathrm{Pd} / \mathrm{C}$ and the $\mathrm{Pd}_{1.3} \mathrm{Ru}_{1.0} / \mathrm{C}$ catalysts, respectively, a fact not observed for the $\mathrm{Pd}_{3.2} \mathrm{Ru}_{1.3}$ $\mathrm{Mo}_{1.0} / \mathrm{C}$ and the $\mathrm{Pd}_{1.5} \mathrm{Ru}_{0.8} \mathrm{Mo}_{1.0} / \mathrm{C}$ catalysts. The catalytic activities were tested for the ethanol oxidation in alkaline medium. Cyclic voltammetry $(\mathrm{CV})$ shows $\mathrm{Pd}_{1.3} \mathrm{Ru}_{1.0} / \mathrm{C}$ exhibiting the highest peak of current density, followed by $\mathrm{Pd}_{3.2} \mathrm{Ru}_{1.3} \mathrm{Mo}_{1.0} / \mathrm{C}$, $\mathrm{Pd}_{1.5} \mathrm{Ru}_{0.8} \mathrm{Mo}_{1.0} / \mathrm{C}$ and $\mathrm{Pd} / \mathrm{C}$. From, chronoamperometry (CA), it is possible to observe the lowest rate of poisoning for the $\mathrm{Pd}_{1.3} \mathrm{Ru}_{1.0} / \mathrm{C}$, followed by $\mathrm{Pd}_{3.2} \mathrm{Ru}_{1.3} \mathrm{Mo}_{1.0} / \mathrm{C}, \mathrm{Pd}_{1.5} \mathrm{Ru}_{0.8} \mathrm{Mo}_{1.0} / \mathrm{C}$ and $\mathrm{Pd} / \mathrm{C}$. These results suggested that catalytic activity of the binary and the ternary catalysts are improved in comparison with $\mathrm{Pd} / \mathrm{C}$. The presence of $\mathrm{RuO}_{2}$ activated the bifunctional mechanism and improved the catalytic activity in the $\mathrm{Pd}_{1.3} \mathrm{Ru}_{1.0} / \mathrm{C}$ catalyst. The addition of Mo in the catalysts enhanced the catalytic activity by the intrinsic mechanism, suggesting a synergistic effect between metals. In summary, we suggest that it is possible to synthesize ternary PdRuMo catalysts supported on Carbon Vulcan XC72, resulting in materials with lower poisoning rates and lower costs than $\mathrm{Pd} / \mathrm{C}$.
\end{abstract}

\section{Graphic abstract}

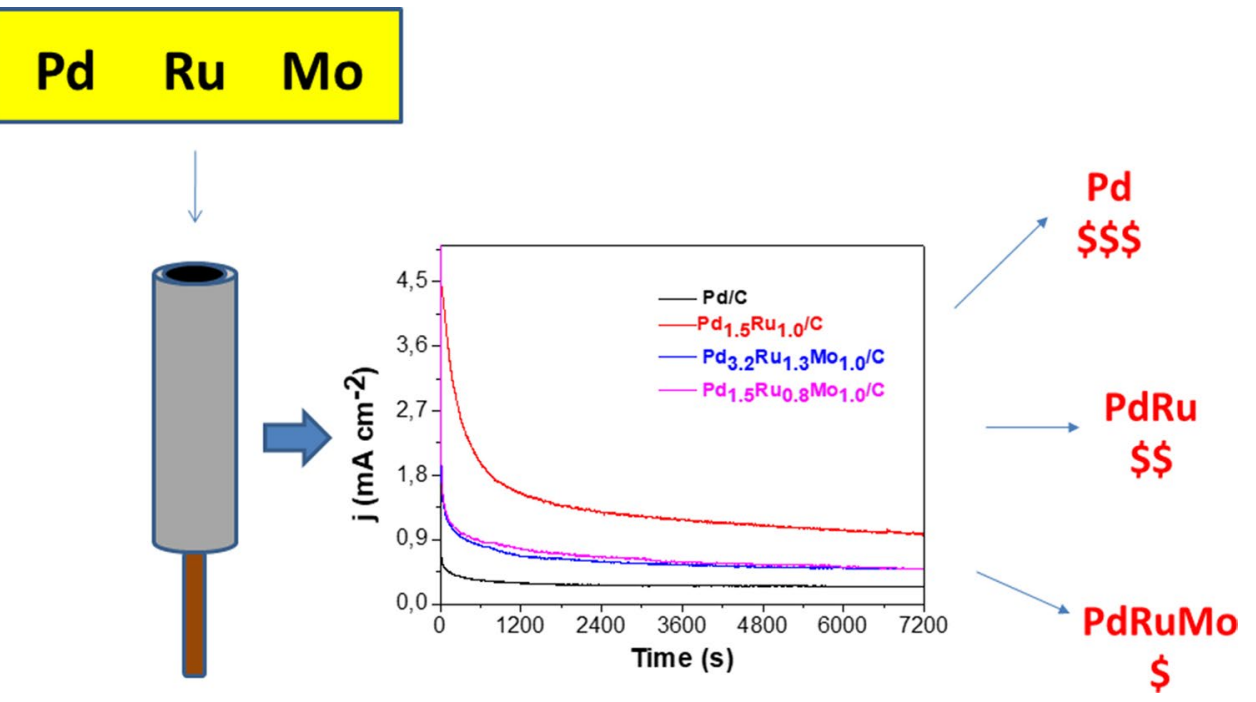

Extended author information available on the last page of the article 
Keywords Palladium-based catalysts $\cdot$ Ruthenium $\cdot$ Molybdenum $\cdot$ Electronic interaction mechanism $\cdot$ Bifunctional mechanism

\section{Introduction}

Fuel cells have sparked a great interest in many research groups as an alternative to generating clean and high-power energy for portable electronics and electric vehicles [1]. Several low molecular weight alcohols (methanol, ethanol, ethylene glycol, isopropanol, and glycerol) have been tested as fuels to replace hydrogen, which generates good power densities and reacts easily with oxygen, but its storage and transportation are difficult [1,2]. Methanol reacts efficiently with oxygen and generates good current densities, but it is toxic and volatile. Ethanol is an alcohol from renewable sources, produces energy with good power densities, and exhibits a remarkably high theoretical efficiency if completely oxidized to $\mathrm{CO}_{2}$ and $\mathrm{H}_{2} \mathrm{O}$. As a result, ethanol seems to be an excellent alternative fuel for fuel cells in mobile devices. However, breaking the ethanol $\mathrm{C}-\mathrm{C}$ bond is not easy and, consequently, the $\mathrm{CO}_{2}$ formation is low, and the incomplete reaction leads to the poisoning $\mathrm{CO}[1,3-6]$

To improve the performance of alcohol fuel cells, it is necessary to use efficient anodic catalysts. Among them, $\mathrm{Pt}$ has shown good results in the acid medium [3-7], but it is a noble metal, its cost is high, and its sources of production are scarce. In addition, Pt-based catalysts are easily poisoned by $\mathrm{CO}$, which decreases its efficiency and leads to undesirable intermediates $[3,5]$.

Due to those reasons, fuel cell research is moving towards other metals to replace $\mathrm{Pt}$ as an anode. For example, $\mathrm{Pd}$ and $\mathrm{Pd}$ alloys have been tested as catalysts and have shown promising results [4-21]. Research groups have been dedicated to investigating the role of Pd and Pd combined with other metals in the oxidation of various alcohols. Bimetallic and trimetallic catalysts, such as $\mathrm{Pd}-\mathrm{M}$ and $\mathrm{Pd}-\mathrm{M}_{1} \mathrm{M}_{2}(\mathrm{M}$, $\mathrm{M}_{1}$ or $\mathrm{M}_{2}=\mathrm{Ru}, \mathrm{Au}, \mathrm{Sn}, \mathrm{Cu}, \mathrm{Ni}, \mathrm{W}, \mathrm{Rh}, \mathrm{Bi}, \mathrm{Nb}, \mathrm{Zr}, \mathrm{Ce}$ and $\mathrm{Mo}$ ), supported in different matrices, aim to decrease the amount of noble metal required and to increase the catalytic activity, minimizing $\mathrm{CO}$ poisoning in ethanol oxidation reaction (EOR) and other alcohols [3, 8-24]. Table 1 presents a summary of the main Pd-based catalysts reported in the literature for EOR.

The results presented in Table 1 show an improvement in the catalytic activity for EOR when the catalysts are Pd alloys, in comparison with catalysts only with Pd, with better tolerance to poisoning, higher current densities, and more negative EOR onset potentials being observed for PdM catalysts.

This is probably due to the intrinsic mechanism (electronic effect), in which the presence of a second or a third metal modifies the electronic structure of Pd, weakening its adsorption of species containing oxygen [19, 25, 26]. Moreover, the added metals not only strongly interact with the adsorbed hydroxyl groups, making bimetallic catalysts more effective than the monometallic ones, but also may lead to rate-determining step for EOR which has less activation energy. [12, 19].

Another important factor that can also explain the lower poisoning tendency and the higher electrochemistry activity of Pd catalysts combined with other metals is the bifunctional mechanism [27-29], in which the oxidation of oxygen-containing species adsorbed on the catalyst surface is facilitated by the presence oxides, which provide oxygenated species for the oxidation of $\mathrm{CO}$ to $\mathrm{CO}_{2}$, releasing the active sites of the noble metal to oxidize the ethanol molecules.

However, the amount of the metals added to Pd must be controlled, as their atoms can decrease the number of sites occupied by Pd on the catalyst surface. As an example, it was observed by Ma et al., Gomes et al. and Carrión-Satorre et al. when the $\mathrm{Pd} / \mathrm{Ru}$ ratio reached 50/50, the catalytic performance decreased, indicating the existence of an ideal amount for the second metal [18-20]. Similarly, the addition of Mo to Pd can facilitate the catalysis in OER through electronic effect, but it was also noted the importance of controlling the amount of Mo added to Pd, reinforcing the existence of an appropriated ratio between metals, since it highly affects the catalytic activities [21,30].

As shown on Table 1, it is common to find Pd-based bimetallic catalysts $(\mathrm{PdM} / \mathrm{C})$ in the literature for direct ethanol fuel cells in alkaline medium. However, the number of works relating $\mathrm{PdM}_{1} \mathrm{M}_{2} / \mathrm{C}$ ternary catalysts is considerably low. As for Pt-based catalysts, the reduction of the amount of Pd on the catalysts, by adding one or more metals to it, makes them cheaper and more efficient for fuel cells. Besides, the literature presents studies regarding PtRu and PdRu catalysts, being observed that PdRu exhibits greater catalytic activity than PtRu in alkaline medium $[5,20,31]$.

Other than Ru, Mo is an interesting metal to form ternary catalysts with Pd, since the literature reports good results with Pt. Strong synergistic effects were observed for the ternary PtRuMo alloy, concluding that the addition of Mo to $\mathrm{Pt}$ and $\mathrm{Ru}$ led to the intrinsic mechanism rather than the bifunctional mechanism, which was not observed [31]. Also, the presence of Mo in PtRu catalyst can lead to a significant decrease in synthesis costs since Mo salts are cheaper than $\mathrm{Pt}$ and Ru salts [32]. In addition, Mo is an oxophilic metal which combined with noble metals shows promising selectivity and activity for oxidation reactions [33].

In this sense, this paper aims to synthesize new Pd-based ternary catalysts with different PdRuMo ratios supported 
Table 1 Summary of the main Pd-based catalysts for EOR

\begin{tabular}{|c|c|c|}
\hline Catalyst & Observed results & References \\
\hline $\mathrm{PdAu}, \mathrm{PdPt}$, and PdPtAu & $\begin{array}{l}\text { The addition of metals decreased the degree of poisoning and increased the peak current density by } 4 \\
\text { times compared to Pd }\end{array}$ & 8 \\
\hline $\mathrm{PdBi}$ & $\begin{array}{l}\text { The addition of a small proportion of Bi improved the catalytic activity by } 2 \text { times higher than that on } \\
\mathrm{Pd} / \mathrm{C}\end{array}$ & 9 \\
\hline $\mathrm{PdSn}$ & Addition of $14 \%$ Sn showed higher current densities than Pd & 10 \\
\hline $\mathrm{PdAg}$ & Addition of $21 \% \mathrm{Ag}$ improved Pd catalytic activity & 11 \\
\hline PdNi, PdSn and PdNiSn & $\begin{array}{l}\text { The onset potential was shifted to more negative values after adding metals, improving electrochemical } \\
\text { activity }\end{array}$ & 12 \\
\hline $\mathrm{PdNi}$ & $\mathrm{Pd}_{40} \mathrm{Ni}_{60}$ presented the best performance for EOR in alkaline environment & 13 \\
\hline $\mathrm{PdCu}$ & $\mathrm{Pd}_{73} \mathrm{Cu}_{27}$ showed better performance and greater tolerance to $\mathrm{CO}$ poisoning & 14 \\
\hline $\mathrm{PdNb}$ & $\mathrm{Pd}_{1} \mathrm{Nb}_{1}$ exhibited a more negative onset potential compared to other proportions $\mathrm{PdNb}$ and $\mathrm{Pd}$ & 15 \\
\hline $\mathrm{PdAu}$ & $\mathrm{Pd}_{3} \mathrm{Au}$ showed better catalytic activity compared to $\mathrm{Pd}$ & 16 \\
\hline \multirow[t]{3}{*}{$\mathrm{PdRu}$} & The incorporation of Ru to Pd resulted in a 4 times higher current density & 17 \\
\hline & $\mathrm{Pd}_{3} \mathrm{Ru}$ ratio increased the power density by almost double & 18 \\
\hline & $\mathrm{Pd}_{12} \mathrm{Ru} / \mathrm{C}$ showed better catalytic activity than the commercial $\mathrm{PtRu} / \mathrm{C}$ & 20 \\
\hline PdMo & $\mathrm{Pd}_{3} \mathrm{Mo} / \mathrm{C}$ showed excellent catalytic activity, high durability and stability & 21 \\
\hline
\end{tabular}

on treated Carbon Vulcan XC72 and test them as anodic catalysts for alkaline direct ethanol fuel cells.

\section{Experimental}

\section{Catalyst preparation}

$\mathrm{Pd}, \mathrm{PdRu}$ and $\mathrm{PdRuMo/C}$ catalysts were synthesized by using the thermal decomposition method starting from their polymeric precursors [34]. $\mathrm{Pd}\left(\mathrm{NO}_{3}\right)_{2} \cdot 2 \mathrm{H}_{2} \mathrm{O}(99 \%$ pure), $\mathrm{RuCl}_{3} \cdot 6 \mathrm{H}_{2} \mathrm{O}$ (99\% pure) and $\mathrm{MoCl}_{5}$ (95\% pure), all acquired from Sigma-Aldrich, were mixed in a solution of anhydrous citric acid (CA) (PA grade; Sigma-Aldrich) and ethylene glycol (EG) (99\% pure Sigma-Aldrich) at a 1:4:16 molar ratio (1 metal salts, $4 \mathrm{CA}$, and $16 \mathrm{EG}$ ) and then added to previously treated Carbon Vulcan XC72 (Carbot). The treatment of Carbon Vulcan is detailed in the supplementary material. The formed suspension was stirred at about $80-90{ }^{\circ} \mathrm{C}$ for $2 \mathrm{~h}$. After this time, the suspension temperature was raised to $130{ }^{\circ} \mathrm{C}$ and allowed to dry. Subsequently, the samples were placed in an oven (Labor SP 1200), heated at $300{ }^{\circ} \mathrm{C}$ for $5 \mathrm{~min}$ and weighed. The procedure was repeated until constant mass (see supplementary material for more details).

\section{Physical characterization}

The obtained catalysts were analyzed by powder X-ray diffraction (XRD), thermal analysis (TG), Scanning Electron Microscopy (SEM), Transmission Electron Microscopy (TEM), X-ray Dispersive Energy Analysis (EDX),
Brunauer-Emmett-Teller (BET) specific surface areas, and Raman spectroscopy.

XRD was performed on a Bruker D8 Advance diffractometer, following the following parameters: $2 \theta=10-90^{\circ}$ step of $0.01^{\circ}, \mathrm{Cu} \mathrm{K \alpha} \alpha_{1}$ radiation (1.54060 $\AA$ ). The diffractograms were evaluated using "Evolution" (EVA) program (Bruker ${ }^{\mathrm{TM}}$ ) and the crystallite sizes were estimated in nanometers by using the Scherrer equation-(Eq. 1), where $\mathrm{D}$ is the estimated crystallite size, $\mathrm{K}$ is the form factor (0.9 for spherical crystallites), $\lambda$ is radiation wavelength (1.5406 $\AA$ ), $\beta$ is the diffraction full width at the half-maximum intensity (FWHM) and $\theta$ is the angle at the maximum intensity $[21,35]$.

$\mathrm{D}=\frac{K \lambda}{\beta \cos \theta}$

The lattice parameters for cubic and tetragonal structures were obtained through Eqs. 2 and 3, respectively, where $d$ is the distance between two successive (hkl) planes and $a$ and $c$ are the lattice parameters [36].

$\frac{1}{d}=\frac{1}{a^{2}}\left(\mathrm{~h}^{2}+\mathrm{k}^{2}+\mathrm{l}^{2}\right)$

$\frac{1}{d}=\frac{h^{2}}{a^{2}}+\frac{k^{2}}{a^{2}}+\frac{l^{2}}{c^{2}}$

Thermal analysis was processed on a Jupiter STA F3 thermal analyzer under $\mathrm{O}_{2}$ atmosphere at a heating rate of $10{ }^{\circ} \mathrm{C} \cdot \mathrm{min}^{-1}$ from 25 to $900{ }^{\circ} \mathrm{C}$. EDX were carried out putting the catalyst samples on a carbon strip attached to an aluminum sample holder and metalized with gold using a Denton Vacuum Desk V metallizer. Then, the images were 
acquired in an apparatus Jeol JSM 6610L (SEM and EDX was performed afterward). BET specific surface areas of the catalysts were measured using Quanta Chrome Autosorb equipment. Raman spectroscopy was performed on the Witec Alpha 300 confocal equipment (Germany), 20× magnification, green laser $(\lambda=532 \mathrm{~nm})$ at $20{ }^{\circ} \mathrm{C}$.

\section{Electrochemical characterization}

Ultrapure water (SARTORIUS mini, Arium ${ }^{\mathrm{TM}}$, model MAUVT) with a resistivity of $18.0 \mathrm{M} \Omega . \mathrm{cm}$ at $22{ }^{\circ} \mathrm{C}$ was used for preparing all the solutions used in the electrochemical tests. Cyclic voltammetry (CV) and Chronoamperometry (CA) were performed with a glassy carbon working electrode (area $0.066 \mathrm{~cm}^{2}$ ), a graphite counter electrode (area $12.05 \mathrm{~cm}^{2}$ ) and a saturated calomel electrode (SCE) (Analyzer, model 3A41) as a reference electrode. The working electrode was previously polished with an alumina suspension ( $\mathrm{n}^{\circ} 3-0.3 \mu \mathrm{m}$ Skill-Tec) and prepared with a catalytic ink, composed by $1.0 \mathrm{mg}$ of catalyst, $95 \mu \mathrm{L}$ ethanol (SigmaAldrich-99\% purity), and $5 \mu \mathrm{L}$ of Nafion ${ }^{\circledR} 117$ (SigmaAldrich) solution, all homogenized for $30 \mathrm{~min}$ in an ultrasonic bath, deposited on its surface and dried at $60^{\circ} \mathrm{C}$.

$\mathrm{CV}$ measurements were performed using a PAR-Ametek VersaStat $4^{\mathrm{TM}}$ potentiostat/galvanostat in the potential range from -0.8 to $0.4 \mathrm{~V}$ vs. SCE, 2 cycles with scan rate of $20 \mathrm{mV} \cdot \mathrm{s}^{-1}$ for $\mathrm{KOH} 1.0 \mathrm{~mol} \mathrm{~L}{ }^{-1}$ and a solution composed by $5.83 \mathrm{~mL}$ ethanol and $100 \mathrm{~mL} \mathrm{KOH} 1.0 \mathrm{~mol} \mathrm{~L}^{-1}$ (KOH, prepared from $90 \%$ purity and ethanol both from Sigma-Aldrich). CA was performed by applying a fixed potential at $-0.4 \mathrm{~V}$ vs. SCE for $2 \mathrm{~h}$ to a solution composed by $5.83 \mathrm{~mL}$ ethanol and $100 \mathrm{~mL} \mathrm{KOH} 1.0 \mathrm{~mol} \mathrm{~L}^{-1}$. The electrolytes were purged with $\mathrm{N}_{2} 5.0$ (99.9\% purity, White Martins) for $10 \mathrm{~min}$.

\section{Results and discussion}

\section{Physical characterization}

The catalysts were synthesized with high yields and the values are shown in Table 2, as well the results of their physical characterizations by EDX, BET surface area and
TGA. According to the thermal analysis (Fig. 1), the ternary catalysts (containing Pd, Ru and Mo) exhibit low remaining mass, or low metal content, at $900{ }^{\circ} \mathrm{C}$. As the thermal analysis was performed under oxygen atmosphere, the carbon support was fully oxidized during the process, leaving only the mass of metallic compounds at the end of the measurement $[12,37]$. This difference between binary and ternary catalysts can be attribute to a lower carbon loss during the calcination step for the ternary catalysts production, leading to a higher carbon content in the ternary catalysts (Table 2) and suggesting a better interaction between the ternary catalysts and their carbon support.

By the remaining metal masses, it was possible to estimate the percentages of the catalysts supported on carbon, which are approximately $50 \%, 48 \%, 30 \%$ and $32 \%$ for $\mathrm{Pd} / \mathrm{C}$, $\mathrm{Pd}_{1.3} \mathrm{Ru}_{1.0} / \mathrm{C}, \mathrm{Pd}_{3.2} \mathrm{Ru}_{1.3} \mathrm{Mo}_{1.0} / \mathrm{C}$ and $\mathrm{Pd}_{1.5} \mathrm{Ru}_{0.8} \mathrm{Mo}_{1.0} / \mathrm{C}$, respectively (Table 2 ). The confirmation of oxide presence on $\mathrm{Pd} / \mathrm{C}$ and $\mathrm{Pd}_{1.3} \mathrm{Ru}_{1.0} / \mathrm{C}$ by thermal analysis is the large loss of mass occurring from $800{ }^{\circ} \mathrm{C}$ and related to the decomposition of oxides [12, 56], a fact observed for $\mathrm{Pd} / \mathrm{C}$ and $\mathrm{Pd}_{1.3} \mathrm{Ru}_{1.0} / \mathrm{C}$ at $900{ }^{\circ} \mathrm{C}$ (Fig. 1).

Figure 2 shows the XRD patterns of the produced catalysts and all samples display typical diffraction peaks at $2 \theta=40.1,46.5,68.1$ and $82^{\circ}$ corresponding to (111), (200), (220) and (311) planes of Pd face-centered cubic (fcc) structure (JCPDS 46-1043) [12, 20, 21]. Peaks at 33.84, 41.93, $54.72,60.2^{\circ}$ and $71.25^{\circ}$ are also observed in the $\mathrm{Pd} / \mathrm{C}$ catalyst and are attributed to the planes (101), (110), (112), (103) and (202) of the PdO tetragonal phase (JCPDS 41-1107) [8, 17-19]. The catalyst $\mathrm{Pd}_{1.3} \mathrm{Ru}_{1.0} / \mathrm{C}$ contains three distinct peaks centered at approximately $28.09,35.1$ and $54.5^{\circ}$, which can be attributed to the presence of $\mathrm{RuO}_{2}$ with a tetragonal structure referring to the planes (110), (101) and (211) (JCPDS 01-0702-662), respectively [20, 27].

The presence of $\mathrm{RuO}_{2}$ may indicate the unsuccessful alloy formation between $\mathrm{Pd}$ and $\mathrm{Ru}$, since studies reported a small amount of Ru dissolved in the fcc structure of Pd [20, 39, 42]. In addition, Fisher et al. [38] suggested that $\mathrm{PdRu}$ alloy can be formed at temperatures below $250^{\circ} \mathrm{C}$ and it was not observed at higher temperatures. The present work synthesized the catalysts at $300{ }^{\circ} \mathrm{C}$ and it can be another reason for the non-alloy formation between $\mathrm{Pd}$ and $\mathrm{Ru}$ on the $\mathrm{Pd}_{1.3} \mathrm{Ru}_{1.0} / \mathrm{C}$ catalyst.
Table 2 Experimental composition obtained by EDX, reaction yield, BET surface area and thermogravimetry data for the catalysts

\begin{tabular}{|c|c|c|c|c|c|}
\hline Theor. composition $(\% \mathrm{~mol})$ & Exp. composition ${ }^{\text {a }}(\% \mathrm{~mol})$ & $\begin{array}{l}\text { Synthesis } \\
\text { yield (\%) }\end{array}$ & $\begin{array}{l}\text { BET area } \\
\left(\mathrm{m}^{2} \mathrm{~g}^{-1}\right)\end{array}$ & $\%$ metal $^{\mathrm{b}}$ & $\%$ carbon $^{\mathrm{b}}$ \\
\hline $\mathrm{Pd} / \mathrm{C}$ & $\mathrm{Pd} / \mathrm{C}$ & 89.4 & 27.5 & 50.0 & 50.0 \\
\hline $\mathrm{Pd}_{1.5} \mathrm{Ru}_{1.0} / \mathrm{C}$ & $\mathrm{Pd}_{1.3} \mathrm{Ru}_{1.0} / \mathrm{C}$ & 90.2 & 100 & 48.0 & 52.0 \\
\hline $\mathrm{Pd}_{7.0} \mathrm{Ru}_{2.0} \mathrm{Mo}_{1.0} / \mathrm{C}$ & $\mathrm{Pd}_{3.2} \mathrm{Ru}_{1.3} \mathrm{Mo}_{1.0} / \mathrm{C}$ & 97.9 & 47.2 & 30.0 & 70.0 \\
\hline $\mathrm{Pd}_{3.0} \mathrm{Ru}_{1.0} \mathrm{Mo}_{1.0} / \mathrm{C}$ & $\mathrm{Pd}_{1.5} \mathrm{Ru}_{0.8} \mathrm{Mo}_{1.0} / \mathrm{C}$ & 98.0 & 38.9 & 32.0 & 68.0 \\
\hline
\end{tabular}

${ }^{\mathrm{a}}$ Results obtained by EDX, ${ }^{\mathrm{b}}$ Estimated by TG 


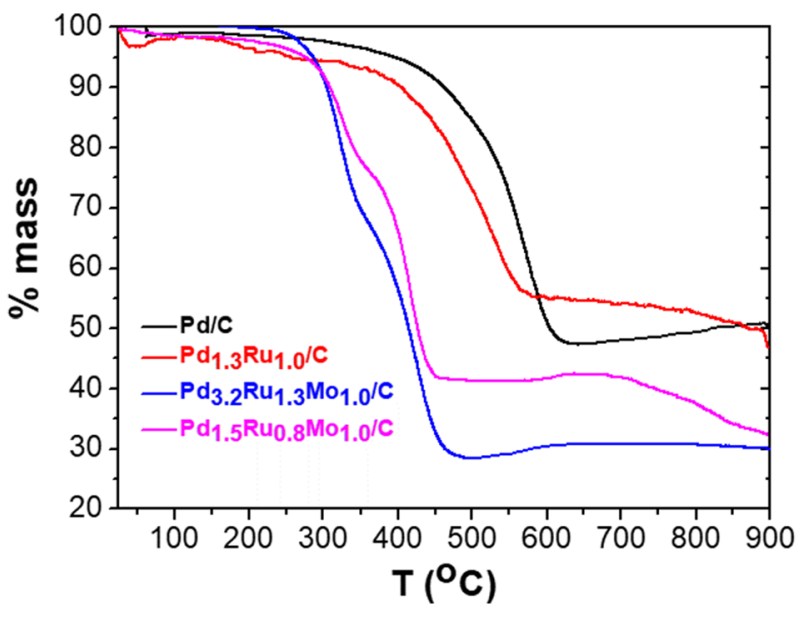

Fig. 1 Thermogravimetric profiles of the developed catalysts

The comparison between the angles of (111) plane of $\mathrm{Pd}$ fcc structure shows that $\mathrm{Pd} / \mathrm{C}, \mathrm{Pd}_{1.3} \mathrm{Ru}_{1.0} / \mathrm{C}$ and $\mathrm{Pd}_{1.5} \mathrm{Ru}_{0.8} \mathrm{Mo}_{1.0} / \mathrm{C}$ present this plane at $40.12,40.12$ and $40.11^{\circ}$, respectively, and $\mathrm{Pd}_{3.2} \mathrm{Ru}_{1.3} \mathrm{Mo}_{1.0} / \mathrm{C}$ presents two distinct phases of cubic Pd: one at $39.06^{\circ}$ (JCPDS 01-0870637) and another at $40.12^{\circ}$ (JCPDS 46-1043). $\mathrm{Pd}_{3.2} \mathrm{Ru}_{1.3}$ $\mathrm{Mo}_{1.0} / \mathrm{C}$ also presents peaks at $45.41,66.17$ and $79.60^{\circ}$ corresponding to (200), (220) and (311) planes of Pd fcc structure (JCPDS 01-087-0637) (Fig. 2). No displacement is observed at $2 \theta$ for $\mathrm{Pd} / \mathrm{C}$ and $\mathrm{Pd}_{1.3} \mathrm{Ru}_{1.0} / \mathrm{C}$, suggesting no alloy formation between $\mathrm{Pd}$ and $\mathrm{Ru}$, a fact observed by Moraes et al. in the study of Pd catalysts [12].

Carrión-Satorre et al. [20] and Monyoncho et al. [39] studied $\mathrm{PdRu} / \mathrm{C}$ catalysts with metal proportions similar to the ones used in this work and suggested ineffective incorporation of $\mathrm{Ru}$ into the $\mathrm{Pd}$ lattice. On the other hand, $\mathrm{Pd}_{3.2} \mathrm{Ru}_{1.3}$ $\mathrm{Mo}_{1.0} / \mathrm{C}$ and $\mathrm{Pd}_{1.5} \mathrm{Ru}_{0.8} \mathrm{Mo}_{1.0} / \mathrm{C}$ present diffraction peak displacements (Table 2), suggesting the formation of alloys as observed by Moraes et al. for Pd catalysts modified by $\mathrm{Ni}$ and $\mathrm{Sn}[12]$.

Table 3 presents the lattice parameters ( $a, b$, and c), volume (V) and the estimated crystallite sizes (D) for the catalysts, calculated by Eqs. 2 and 3 respectively. The addition of metals with atomic radius greater than $\mathrm{Pd}(1.28 \AA)$ to its structure, as in the case of Mo (1.29 $\AA$ ), increases the lattice parameters, thus indicating an expansion of the crystalline lattice. This fact has been reported in the literature, where metals with atomic radius greater than $\mathrm{Pd}$, such as $\mathrm{Au}$ $(1.34 \AA)$ and Sn $(1.40 \AA)$, increased its lattice parameters when added to it [40].

The estimated crystallite sizes of the produced catalysts were calculated by Eq. 1, measuring between 16.0 and $47.0 \mathrm{~nm}$ for Pd fcc phase. These values do not match those reported in the literature, where crystallite sizes between 4 and $15 \mathrm{~nm}$ were observed. Possible reasons for

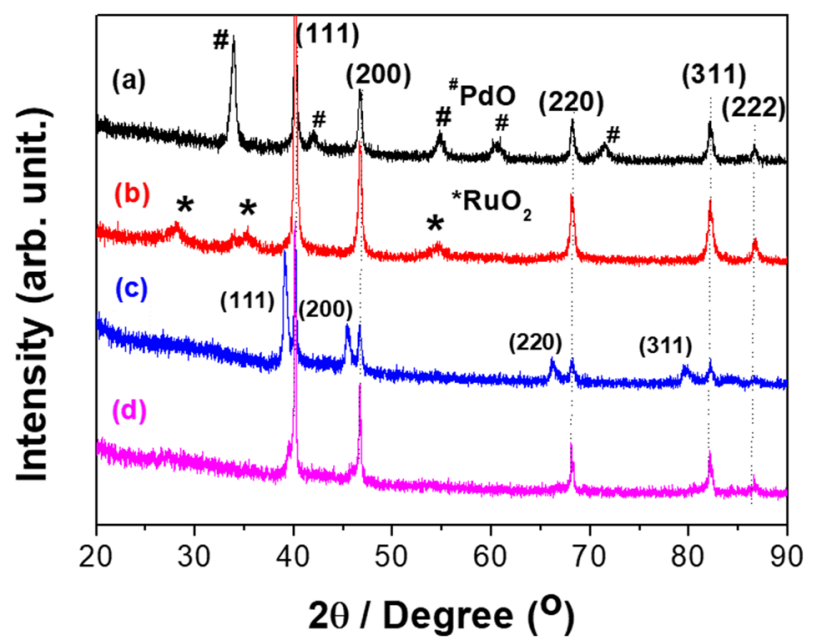

Fig. 2 - XRD patterns of a $\mathrm{Pd} / \mathrm{C}, \mathbf{b} \mathrm{Pd}_{1.3} \mathrm{Ru}_{1.0} / \mathrm{C}, \mathbf{c} \mathrm{Pd}_{3.2} \mathrm{Ru}_{1.3} \mathrm{Mo}_{1.0} / \mathrm{C}$ and $\mathbf{d} \mathrm{Pd}_{1.5} \mathrm{Ru}_{0.8} \mathrm{Mo}_{1.0} / \mathrm{C}$

this discrepancy are related to the synthesis method adopted and the metal/carbon ratio used [10-12]. Based on the metal/ carbon ratio, Pillai et al. [35] studied catalysts with metal/ carbon ratios between 20 and $40 \%$ and prepared them by metal reduction with formic acid technique and observed an increase in the crystallite size when the metal proportion was around $30 \%$. Similar behavior is observed for the catalysts $\mathrm{Pd}_{3.2} \mathrm{Ru}_{1.3} \mathrm{Mo}_{1.0} / \mathrm{C}$ and $\mathrm{Pd}_{1.5} \mathrm{Ru}_{0.8} \mathrm{Mo}_{1.0} / \mathrm{C}$ prepared in this work by the technique using citric acid, which present metallic loads around 30 and $32 \%$, respectively. Concerning the synthesis method, this work adopted a method not reported in the literature for the preparation of Pd ternary catalysts and it can explain the production of crystallites with sizes higher than the values reported (Table 2), since the preparation technique is one of the factors that affect the structure of the particles [41]. In addition, it is important to emphasize that Eq. 1 determines, more accurately crystallite size of spherical particles [35].

Figure 3 shows the Raman spectra, and it is possible to see peaks of greater intensity related to $\mathrm{PdO}$ and $\mathrm{RuO}_{2}$. $\mathrm{Pd} / \mathrm{C}$ shows typical PdO Raman spectrum, with the most intense peak at $646 \mathrm{~cm}^{-1}$. McBride et al. [43] and Zhao et al. [44] obtained similar spectrum at room temperature for $\mathrm{PdO}$, with the most intense peak at $648 \mathrm{~cm}^{-1}$, which is very close to the value found in this work. Therefore, the results presented by Raman spectroscopy are in accordance with the TG and XRD results, proving the formation of $\mathrm{PdO}$ on the $\mathrm{Pd} / \mathrm{C}$ catalyst. $\mathrm{Pd}_{57} \mathrm{Ru}_{43} / \mathrm{C}$ shows Raman displacement values at 628 and $698 \mathrm{~cm}^{-1}$. Shin et al. [45] and Meng et al. [46] obtained these values at room temperature for the $\mathrm{RuO}_{2}$ spectrum. The result of Raman spectroscopy for $\mathrm{Pd}_{1.3} \mathrm{Ru}_{1.0} / \mathrm{C}$ also agrees with its XRD results. $\mathrm{Pd}_{3.2} \mathrm{Ru}_{1.3}$ $\mathrm{Mo}_{1.0} / \mathrm{C}$ and $\mathrm{Pd}_{1.5} \mathrm{Ru}_{0.8} \mathrm{Mo}_{1.0} / \mathrm{C}$ do not show Raman displacements for oxides (Fig. 3), confirming the results of TG 
Table 3 Physical characterization of catalysts using XRD

\begin{tabular}{|c|c|c|c|c|c|c|c|c|}
\hline \multirow[t]{2}{*}{ Catalyst } & \multirow[t]{2}{*}{ Phase } & \multirow[t]{2}{*}{$\mathrm{a}=\mathrm{b}(\AA)$} & \multirow[t]{2}{*}{ c $(\AA)$} & \multirow[t]{2}{*}{$\mathrm{V}\left(\AA^{3}\right)$} & \multicolumn{4}{|c|}{$\mathrm{D}(\mathrm{nm}) \mathrm{Pd}$} \\
\hline & & & & & (111) & $(200)$ & (220) & (311) \\
\hline \multirow[t]{2}{*}{$\mathrm{Pd} / \mathrm{C}$} & $P d$ & 3.890 & - & 58.9 & 28.4 & 19.5 & 19.6 & 16.4 \\
\hline & $P d O$ & 3.046 & 5.339 & 49.5 & - & - & - & - \\
\hline \multirow[t]{2}{*}{$\mathrm{Pd}_{1.3} \mathrm{Ru}_{1.0} / \mathrm{C}$} & $P d$ & 3.890 & - & 58.9 & 28.7 & 19.9 & 16.9 & 14.9 \\
\hline & $\mathrm{RuO} \mathrm{O}_{2}$ & 4.489 & 3.105 & 62.6 & - & - & - & - \\
\hline \multirow[t]{2}{*}{$\mathrm{Pd}_{3.2} \mathrm{Ru}_{1.3} \mathrm{Mo}_{1.0} / \mathrm{C}$} & $P d^{*}$ & 3.890 & - & 58.9 & 47.0 & 31.2 & 28.1 & $\begin{array}{l}23.6 \\
23.5\end{array}$ \\
\hline & $P d * *$ & 3.991 & & 63.6 & 47.0 & 31.1 & 28.0 & 23.5 \\
\hline $\mathrm{Pd}_{1.5} \mathrm{Ru}_{0.8} \mathrm{Mo}_{1.0} / \mathrm{C}$ & $P d$ & 3.891 & - & 58.9 & 46.9 & 36.1 & 28.4 & 23.7 \\
\hline
\end{tabular}

$* 2 \theta=40.12^{\circ} * * 2 \theta=39.06^{\circ}$; lattice parameters ( $\mathrm{a}, \mathrm{b}$ and c), volume $(\mathrm{V})$ and the estimated crystallite sizes (D) for the catalysts; $P d$ face centered cubic (fcc); $\mathrm{PdO}$ and $\mathrm{RuO}_{2}-$ Tetragonal and XRD, where no oxides were observed for those catalysts, suggesting the more effective incorporation of Ru and Mo into the palladium structure. In summary, the results achieved by TG, XRD and Raman suggest the formation of alloys on $\mathrm{Pd}_{3.2} \mathrm{Ru}_{1.3} \mathrm{Mo}_{1.0} / \mathrm{C}$ and $\mathrm{Pd}_{1.5} \mathrm{Ru}_{0.8} \mathrm{Mo}_{1.0} / \mathrm{C}$, but not on $\mathrm{Pd}_{1.3} \mathrm{Ru}_{1.0} / \mathrm{C}$.

BET surface areas for $\mathrm{Pd} / \mathrm{C}, \mathrm{Pd}_{1.3} \mathrm{Ru}_{1.0} / \mathrm{C}, \mathrm{Pd}_{3.2} \mathrm{Ru}_{1.3}$ $\mathrm{Mo}_{1.0} / \mathrm{C}, \mathrm{Pd}_{1.5} \mathrm{Ru}_{0.8} \mathrm{Mo}_{1.0} / \mathrm{C}$ were 27.5, 100, 47.2 and 38.9 $\mathrm{m}^{2} \mathrm{~g}^{-1}$, respectively (Table 2). In comparison to treated Cvulcan, there is a considerable decrease in its BET surface area after the production of the catalysts $\left(211.1 \mathrm{~m}^{2} \mathrm{~g}^{-1}\right.$ - supplementary material). The reduction in the surface area of the carbon is noticeable when impregnated with metal, indicating the existence of metal nanoparticles on its surface. This can be explained by the pore clogging caused by the metals, leading to a decrease in the support surface area [36, 46]. In addition, a smaller surface area indicates a better particles distribution on the support, preventing the absorption of nitrogen $[47,48]$.

\section{Electrochemical measurements}

Figure 4 shows voltammetric profile of the catalysts in alkaline medium with similar anodic and cathodic current densities in the potential range between $-0.8 \mathrm{~V}$ and $0.4 \mathrm{~V}$ vs SCE. This potential range was adopted by the fact that voltammetric curve for compounds with Pd usually present three distinct regions during the scan: the so-called hydrogen region, observed from -0.8 to $-0.4 \mathrm{~V}$ : the oxidation region of $\mathrm{Pd}$ to $\mathrm{PdO}$, observed in the potential range between -0.4 and $0.4 \mathrm{~V}$ and the $\mathrm{PdO}$ reduction, observed between -0.6 and $-0.4 \mathrm{~V}[12,20]$.

In Fig. $4 \mathrm{a}$ it is possible to see the peaks of cathodic potentials $\left(\mathrm{E}_{\text {cat }}\right)$, also defined in Table 4 , for all the catalysts. $\mathrm{Pd} / \mathrm{C}$ shows a peak of $\mathrm{PdO}$ reduction at $-0.40 \mathrm{~V}$, related to $\mathrm{PdO}+\mathrm{H}_{2} \mathrm{O}+\mathrm{e}^{-} \rightarrow \mathrm{Pd}+2 \mathrm{OH}^{-}$(Eq. 4) [8]. In the $\mathrm{Pd}_{1.3} \mathrm{Ru}_{1.0} / \mathrm{C}$ catalyst, the presence of $\mathrm{Ru}$ displaces the cathodic peak to $\mathrm{E}=-0.30 \mathrm{~V}$, a fact explained by the

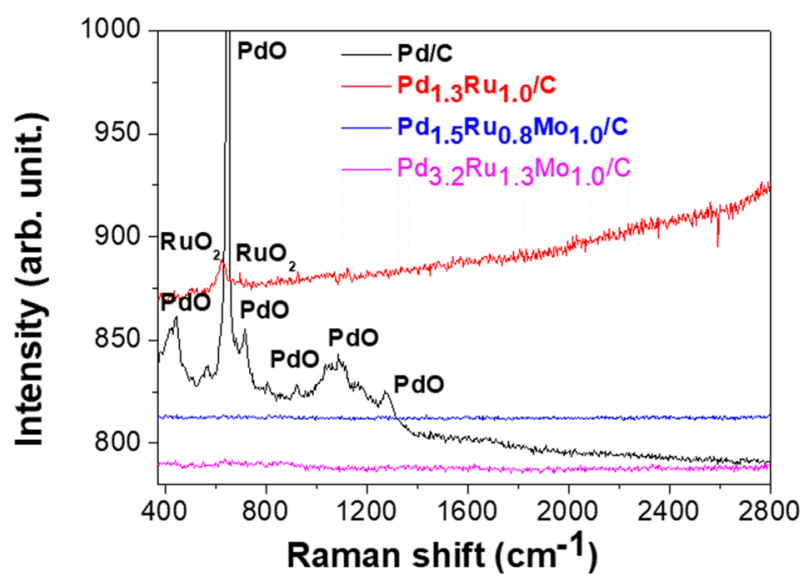

Fig. 3 Raman spectra for catalysts at $20^{\circ} \mathrm{C}$, excited by a 532 -nm laser and $20 \mathrm{X}$ magnificaction

reduction of ruthenium oxides [20]. The displacement of $\mathrm{E}_{\text {cat }}$ values for $\mathrm{Pd}_{3.2} \mathrm{Ru}_{1.3} \mathrm{Mo}_{1.0} / \mathrm{C}$ and $\mathrm{Pd}_{1.5} \mathrm{Ru}_{0.8} \mathrm{Mo}_{1.0} / \mathrm{C}$ catalysts may be related to the stronger interaction of $\mathrm{Ru}$ and $\mathrm{Mo}$ with Pd, corroborated by the formation of oxides for these catalysts.

Figure $4 \mathrm{~b}$ shows the cyclic voltammograms of the catalysts in $\mathrm{KOH} /$ ethanol medium and Table 4 shows their electrochemical parameters. Two peaks are observed in the ethanol voltammograms and are relative to its oxidation. In the forward scan, the observed peak corresponds to the oxidation of species adsorbed in the catalysts generated by the dissociative adsorption of ethanol. In the backward scan, the peak is related to the removal of carbonaceous species not completely oxidized in the forward scan [22]. According to Hammed [49], the oxidation reaction of ethanol on $\mathrm{Pd}$ results from the adsorption of ethanol on the electrocatalytic surface, where it is not completely oxidized in an alkaline medium and can be represented by Eqs. 4, 5, 6 and 7 . 
$\mathrm{Pd}+\mathrm{CH}_{3} \mathrm{CH}_{2} \mathrm{OH} \rightarrow \mathrm{Pd}\left(\mathrm{CH}_{3} \mathrm{CH}_{2} \mathrm{OH}\right)_{\text {ads }}$

$\mathrm{Pd}\left(\mathrm{CH}_{3} \mathrm{CH}_{2} \mathrm{OH}\right)_{\text {ads }}+3 \mathrm{OH}^{-} \rightarrow \mathrm{Pd}\left(\mathrm{CH}_{3} \mathrm{CO}\right)_{\text {ads }}+3 \mathrm{H}_{2} \mathrm{O}+3 \mathrm{e}^{-}$
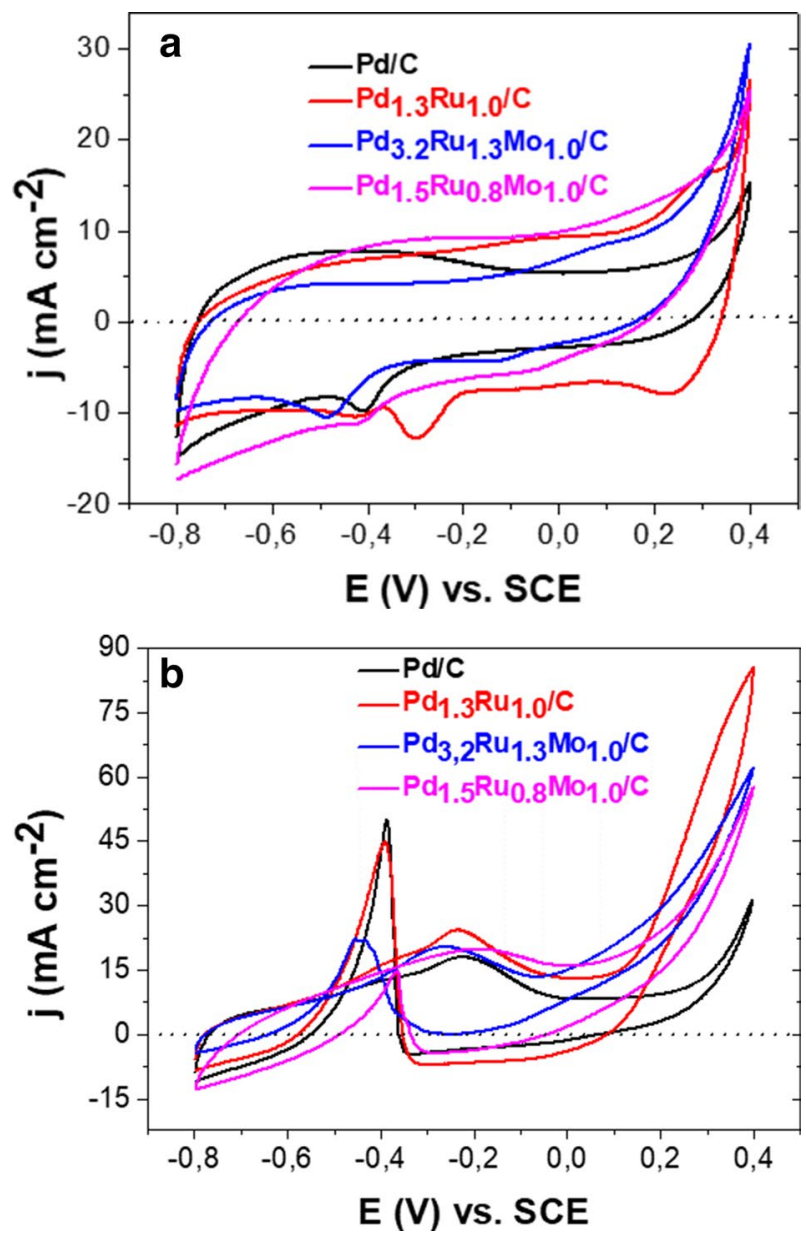

Fig. 4 Cyclic voltammograms of the catalysts in different electrolytes a $\mathrm{KOH} 1.0 \mathrm{~mol} \cdot \mathrm{L}^{-1}$ and b $\mathrm{KOH} 1.0 \mathrm{~mol} \mathrm{~L}^{-1} / \mathrm{ethanol}$
$\mathrm{Pd}\left(\mathrm{CH}_{3} \mathrm{CO}\right)_{\mathrm{ads}}+\mathrm{Pd}(\mathrm{OH})_{\mathrm{ads}} \rightarrow \mathrm{Pd}\left(\mathrm{CH}_{3} \mathrm{COOH}\right)_{\mathrm{ads}}+\mathrm{Pd}$

$\mathrm{Pd}\left(\mathrm{CH}_{3} \mathrm{COOH}\right)_{\mathrm{ads}}+\mathrm{OH}^{-} \rightarrow \mathrm{Pd}+\mathrm{CH} 3 \mathrm{COO}^{-}+\mathrm{H}_{2} \mathrm{O}$

The EOR initiation potential $\left(\mathrm{E}_{\text {onset }}\right)$ shows more negative values for the catalysts containing metals added to $\mathrm{Pd}$ (Table 4). This fact suggests not only a greater facility to initiate the reaction (Eq. 4) [12], but also to modify the Pd/C structure by adding Ru and Mo to Pd catalysts, favoring the catalysis of the EOR. Maximum values of current density for anodic oxidation peak $\left(j_{\text {peak }}\right)$ are also observed. The $\mathrm{Pd}_{1.3} \mathrm{Ru}_{1.0} / \mathrm{C}$ catalyst shows the highest $j_{\text {peak }}$ value and the greatest variation of the oxidation peak compared to $\mathrm{Pd} / \mathrm{C}$, followed by the $\mathrm{Pd}_{3.2} \mathrm{Ru}_{1.3} \mathrm{Mo}_{1.0} / \mathrm{C}$ and $\mathrm{Pd}_{1.5} \mathrm{Ru}_{0.8} \mathrm{Mo}_{1.0} / \mathrm{C}$ catalysts.

The greatest catalytic performance exhibited by $\mathrm{Pd}_{1.3} \mathrm{Ru}_{1.0} / \mathrm{C}$ can be related to four factors $[12,20,50]$ : crystallite size, BET surface area, electronic effect and bifunctional mechanisms. $\mathrm{Pd}_{1.3} \mathrm{Ru}_{1.0} / \mathrm{C}$ shows the larges BET surface area and the smallest average crystallite size (Tables 2 and 3), which facilitates the passage of electrons on the catalyst surface during the EOR. In addition, the presence of $\mathrm{RuO}_{2}$ favors the bifunctional mechanism, with the oxide favoring the oxidation of $\mathrm{CO}$ to $\mathrm{CO}_{2} \cdot \mathrm{Pd}_{3.2} \mathrm{Ru}_{1.3} \mathrm{Mo}_{1.0} / \mathrm{C}$ and $\mathrm{Pd}_{1.5} \mathrm{Ru}_{0.8} \mathrm{Mo}_{1.0} / \mathrm{C}$ show larger crystallite sizes, suggesting their catalytic activities are not due to this factor, but are related to the BET surface area (Table 2) and to the electronic effect mechanism generated by the alloys formed between the metals, which modify their electronic structures, reducing the activation energy required for the EOR $[16,17]$.

Chronoamperometry is an important electrochemical technique for the evaluation of catalytic activity and stability of $\mathrm{PdM} / \mathrm{C}$ and $\mathrm{PdM}_{1} \mathrm{M}_{2} / \mathrm{C}$ catalysts in EOR. In this sense, Fig. 5 shows the chronoamperometric curves for ethanol oxidation at $-0.4 \mathrm{~V}$, since it was observed that the region between -0.6 and $-0.4 \mathrm{~V}$ could give us an idea of the trends
Table 4 Electrochemical data obtained by cyclic voltammetry and chronoamperometry

\begin{tabular}{lllllll}
\hline Catalyst & $\mathrm{mPd}(\mathrm{mg})$ & $E_{\text {cat }}(\mathrm{V})^{\mathrm{a}}$ & $E_{\text {onset }}(\mathrm{V})^{\mathrm{b}}$ & $j_{\text {peak }}\left(\mathrm{mA} \mathrm{cm}^{-2}\right)^{\mathrm{c}}$ & $\begin{array}{l}j-0.4 \mathrm{~V} \\
(\mathrm{~mA} \\
\left.\mathrm{cm}^{-2}\right)^{\mathrm{d}}\end{array}$ & \\
\hline $\mathrm{Pd} / \mathrm{C}$ & 0.5725 & 0.40 & -0.65 & 18.1 & $10^{-4}\left(\% \mathrm{~s}^{-1}\right)^{\mathrm{e}}$ \\
$\mathrm{Pd}_{1.3} \mathrm{Ru}_{1.0} / \mathrm{C}$ & 0.3118 & 0.30 & -0.72 & 23.5 & 16.4 & -0.854 \\
$\mathrm{Pd}_{3.2} \mathrm{Ru}_{1.3} \mathrm{Mo}_{1.0} / \mathrm{C}$ & 0.2431 & 0.48 & -0.69 & 20.4 & 14.0 & $-3,41$ \\
$\mathrm{Pd}_{1.5} \mathrm{Ru}_{0.8} \mathrm{Mo}_{1.0} / \mathrm{C}$ & 0.2046 & 0.44 & -0.68 & 20.0 & 14.3 & -1.81 \\
\hline
\end{tabular}

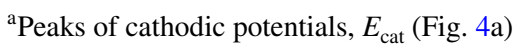

${ }^{\mathrm{b}}$ EOR initiation potential, $E_{\text {onset }}$ (Fig. 4b)

${ }^{\mathrm{c}}$ Maximum current density, $j_{\text {peak }}$ (Fig. 4b)

${ }^{\mathrm{d}}$ Current density at $-0.4 \mathrm{~V}$ vs. SCE, $j_{-0.4 \mathrm{~V}}$ (Fig. 4b)

${ }^{\mathrm{e}}$ Poisoning rate, $\delta$ (Eq. 9) 
that can be observed in a fuel cell with PdRu-based catalysts [20].

During the first minutes of analysis, a sharp reduction in the current is observed and it is followed by a slower decline over the time. At the beginning, the active sites of the catalysts are free of adsorbed organic molecules $\left(\mathrm{CH}_{3} \mathrm{CH}_{2} \mathrm{OH}\right.$, $\mathrm{CH}_{3} \mathrm{CO}$ and $\mathrm{CH}_{3} \mathrm{COOH}$ ) and it promotes high adsorption rates. However, as the time passes, the active sites become fully occupied and the adsorption of a new ethanol molecule occurs only after the releasing of a site, causing the poisoning of the active sites by these molecules. Stabilization is observed at, approximately, 300, 1000, and $600 \mathrm{~s}$ for $\mathrm{Pd} / \mathrm{C}, \mathrm{Pd}_{1.3} \mathrm{Ru}_{1.0} / \mathrm{C}, \mathrm{Pd}_{3.2} \mathrm{Ru}_{1.3} \mathrm{Mo}_{1.0} / \mathrm{C}$ and $\mathrm{Pd}_{1.5} \mathrm{Ru}_{0.8} \mathrm{Mo}_{1.0} / \mathrm{C}$ catalysts, respectively (Fig. 5). Poisoning rate $(\delta)$ can be calculated through Eq. 9 by measuring the linear decay of the current density over a time greater than $300 \mathrm{~s}$ [20].

$\delta=\frac{100}{i} \times \frac{d j}{d t}\left(\% \mathrm{~s}^{-1}\right)$

where $\mathrm{dj} / \mathrm{dt}$ is the slope of the linear portion of the current density decay and $i$ is the current density at $-0.4 \mathrm{~V}$ (Fig. 5). The calculated values for $\delta$ are shown in Table 4 .

It can be seen from Table 4 that adding metals to $\mathrm{Pd}$ shifts $\delta$ to more negative values, suggesting that added metals contribute to decrease the poisoning rate of binary and ternary catalysts. $\mathrm{Pd}_{1,3} \mathrm{Ru}_{1.0} / \mathrm{C}$ shows the lowest $\delta$ value and the longest stabilization time (approximately $1000 \mathrm{~s}$ ) and this is maybe due to the presence of $\mathrm{Ru}$, a chemical element more oxyphilic than Pd on the catalyst. Ru may favor the formation of oxidized species $\left(\mathrm{RuO}_{2}\right)$ on the surface of the material and this oxide activates oxygen atoms in the EOR, favoring the reaction and making the catalyst more resistant to poisoning [20]. $\mathrm{Pd}_{3.2} \mathrm{Ru}_{1.3} \mathrm{Mo}_{1.0} / \mathrm{C}$ and $\mathrm{Pd}_{1.5} \mathrm{Ru}_{0.8} \mathrm{Mo}_{1.0} / \mathrm{C}$ instead show intermediate values of stabilization time (approximately $600 \mathrm{~s}$ ) and more negative $\delta$ values compared to $\mathrm{Pd} / \mathrm{C}$ catalyst, but more positive than $\mathrm{Pd}_{1.3} \mathrm{Ru}_{1.0} / \mathrm{C}$ catalyst. This fact can also be explained by the electronic effect mechanism, in which the metals added to the Pd modify its electronic structure and form alloys with Pd, reducing both the poisoning of the active sites of the catalysts and the EOR activation energy [16]. These facts confirm CV results, with $\mathrm{Pd}_{1.3} \mathrm{Ru}_{1.0} / \mathrm{C}$ showing greater catalytic activity for $\mathrm{EOR}$, followed by $\mathrm{Pd}_{3.2} \mathrm{Ru}_{1.3} \mathrm{Mo}_{1.0} / \mathrm{C}, \mathrm{Pd}_{1.5} \mathrm{Ru}_{0.8} \mathrm{Mo}_{1.0} / \mathrm{C}$ and $\mathrm{Pd} / \mathrm{C}$ (Fig. 5 and Table 4), being also the most stable and the most poisoning resistant catalyst.

Petrii [31] reported that PtRu catalysts had a high tolerance to $\mathrm{CO}$ and facilitated the oxidation of $\mathrm{CO}$ to $\mathrm{CO}_{2}$, due to the bifunctional mechanism, where the presence of $\mathrm{Ru}$ strongly modified the surface of $\mathrm{Pt}$ and activated oxygen species. Thus, the performance of $\mathrm{PtRuMo/C}$ catalysts for the ethanol oxidation could be is related to the high affinity of their oxides in relation to the $\mathrm{OH}$ species, providing

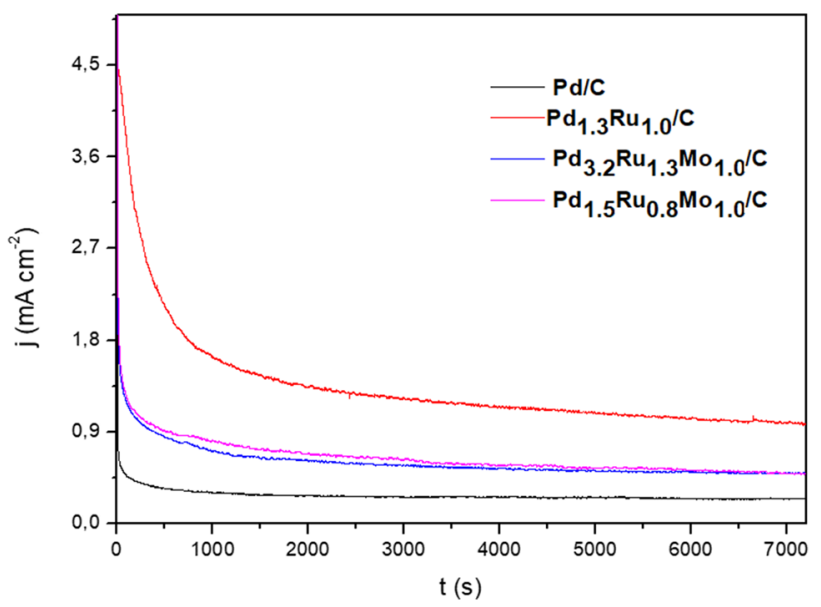

Fig. 5 Chronoamperometry curves in $\mathrm{KOH} 1.0 \mathrm{~mol} \cdot \mathrm{L}^{-1} /$ Ethanol solution for $2 \mathrm{~h}$

species of oxygen at the surface of the catalyst with lower potential compared to pure Pd catalysts. That is, the presence of $\mathrm{Ru}$ and/or Mo maybe favors the bi-functional mechanism and can accelerate the dissociation of $\mathrm{H}_{2} \mathrm{O}$ molecules to form $\mathrm{OH}_{\mathrm{ads}}$, facilitating the oxidation of adsorbed alcohols or poisons, thus recovering the active sites of $\mathrm{Pd}$ so that the oxidation reaction continues. Therefore, due to the similarities between $\mathrm{Pt}$ and $\mathrm{Pd}$, similar behavior is expected, a fact observed in the intermediate behavior of the poisoning rate of $\mathrm{Pd}_{3.2} \mathrm{Ru}_{1.3} \mathrm{Mo}_{1.0} / \mathrm{C}$ and $\mathrm{Pd}_{1.5} \mathrm{Ru}_{0.8} \mathrm{Mo}_{1.0} / \mathrm{C}$, lower poisoning rate of $\mathrm{Pd}_{1.3} \mathrm{Ru}_{1.0} / \mathrm{C}$ (Table 4) and stabilization time $\left(\mathrm{Pd}_{1.3} \mathrm{Ru}_{1.0} / \mathrm{C} \sim 300 ; \mathrm{Pd}_{3.2} \mathrm{Ru}_{1.3} \mathrm{Mo}_{1.0} / \mathrm{C}\right.$ and $\mathrm{Pd}_{1.5} \mathrm{Ru}_{0.8} \mathrm{Mo}_{1.0} / \mathrm{C} \sim 600 \mathrm{~s}-$ Fig. 5).

\section{Perspectives}

The main challenges for the development of new materials for ethanol fuel cells are related to the catalyst poisoning, which decreases its efficiency, and the high cost of the Pd salts used for the preparation of the catalysts. Nowadays, the average price of $1 \mathrm{~g}$ of $\mathrm{Pd}\left(\mathrm{NO}_{3}\right)_{2} \cdot 2 \mathrm{H}_{2} \mathrm{O}$ used in this work, is about US\$ 150.00 [51]. Both poisoning and material cost can be reduced by lowering the amount of Pd on the catalyst, either by increasing the amount of the support or adding metals less nobles. Table 5 shows the comparison between the results obtained for $\mathrm{Pd}_{1.3} \mathrm{Ru}_{1.0} / \mathrm{C}, \mathrm{Pd}_{3.2} \mathrm{Ru}_{1.3} \mathrm{Mo}_{1.0} / \mathrm{C}$ and $\mathrm{Pd}_{1.5} \mathrm{Ru}_{0.8} \mathrm{Mo}_{1.0} / \mathrm{C}$ in relation to $\mathrm{Pd} / \mathrm{C}$. This table brings the amount of Pd (considering Pd/C 100\%), the percentage of the maximum oxidation peak variation $\left(\Delta_{\text {jpeak }}\right)$, the approximate increase in the percentage of the average time to initiate the catalyst poisoning $(\% t)$, the decrease in the percentage of poisoning $(\Delta \delta)$ and the percentage of cost reduction in relation to $\mathrm{Pd} / \mathrm{C}(\%$ \$), with the value of US\$ $150.00 / \mathrm{g}$ of the Pd salt being reduced. 
From the data presented in Table 5, the three catalysts prove to be more efficient than $\mathrm{Pd} / \mathrm{C} . \mathrm{Pd}_{1.3} \mathrm{Ru}_{1.0} / \mathrm{C}$ shows the highest variation in the maximum oxidation peak, the lowest propensity for poisoning and the longest stability. However, due to the higher percentage of $\mathrm{Pd}$, it would have a higher cost compared to $\mathrm{Pd}_{3.2} \mathrm{Ru}_{1.3} \mathrm{Mo}_{1.0} / \mathrm{C}$ and $\mathrm{Pd}_{1.5} \mathrm{Ru}_{0.8} \mathrm{Mo}_{1.0} / \mathrm{C}$. $\mathrm{Pd}_{3.2} \mathrm{Ru}_{1.3} \mathrm{Mo}_{1.0} / \mathrm{C}$ shows a lower peak of current density and an increase in the percentage of poisoning by about $28 \%$ in relation to $\mathrm{Pd}_{1.3} \mathrm{Ru}_{1.0} / \mathrm{C}$. So, $\mathrm{Pd}_{3.2} \mathrm{Ru}_{1.3} \mathrm{Mo}_{1.0} / \mathrm{C}$ can be considerably less stable than $\mathrm{Pd}_{1.3} \mathrm{Ru}_{1.0} / \mathrm{C}$, but due to its lower percentage of $\mathrm{Pd}$ it decreases its cost. $\mathrm{Pd}_{1.5} \mathrm{Ru}_{0.8} \mathrm{Mo}_{1.0} / \mathrm{C}$ shows similar results to $\mathrm{Pd}_{3.2} \mathrm{Ru}_{1.3} \mathrm{Mo}_{1.0} / \mathrm{C}$ and a small variation in the cost in relation to the total cost. Therefore, analyzing the values presented in Table 5 , it is possible the development of alloys with Pd, Ru and Mo on carbon Vulcan as support aiming to decrease the poisoning rate and the cost of these catalysts. We encourage the performance of other tests with the catalysts of this [52-55] work to study their

Table 5 Comparison between the results obtained for $\mathrm{Pd}_{1.3} \mathrm{Ru}_{1.0} / \mathrm{C}$, $\mathrm{Pd}_{3.2} \mathrm{Ru}_{1.3} \mathrm{Mo}_{1.0} / \mathrm{C}$ and $\mathrm{Pd}_{1.5} \mathrm{Ru}_{0.8} \mathrm{Mo}_{1.0} / \mathrm{C}$ in relation to $\mathrm{Pd} / \mathrm{C}$

\begin{tabular}{lccccc}
\hline Catalyst & $\% \mathrm{Pd}$ & $\Delta j_{\text {peak }}(\%)^{\mathrm{a}}$ & $\% t^{\mathrm{b}}$ & $\Delta \delta(\%)^{\mathrm{c}}$ & $\% \$^{\mathrm{d}}$ \\
\hline $\mathrm{Pd}_{1.3} \mathrm{Ru}_{1.0} / \mathrm{C}$ & 54.5 & 22.9 & 70 & 86.8 & 45.2 \\
$\mathrm{Pd}_{3.2} \mathrm{Ru}_{1.3} \mathrm{Mo}_{1.0} / \mathrm{C}$ & 42.5 & 11.3 & 50 & 75.0 & 57.3 \\
$\mathrm{Pd}_{1.5} \mathrm{Ru}_{0.8} \mathrm{Mo}_{1.0} / \mathrm{C}$ & 35.5 & 9.50 & 50 & 53.8 & 64.1 \\
\hline
\end{tabular}

a Percentage of the maximum oxidation peak variation, $\Delta j_{\text {peak }}$

${ }^{b}$ Approximate increase in the percentage of the average time to initiate the catalyst poisoning, $t$

${ }^{\mathrm{c}}$ Decrease in the percentage of poisoning, $\Delta \delta$

${ }^{\mathrm{d}}$ Percentage of cost reduction in relation to $\mathrm{Pd} / \mathrm{C}$ properties, as well as the synthesis and characterization of new proportions of the PdRuMo alloy, to obtain a greater reduction in the degree of poisoning and greater decrease in the cost of these materials. Concluding, the Table 6 presents a summary of the main characteristics and differences between the catalysts evaluated in this work, where we observed that $\mathrm{Pd}_{3.2} \mathrm{Ru}_{1.3} \mathrm{Mo}_{1.0} / \mathrm{C}$ and $\mathrm{Pd}_{1.5} \mathrm{Ru}_{0.8} \mathrm{Mo}_{1.0} / \mathrm{C}$ can have a low cost compared to $\mathrm{Pd} / \mathrm{C}$ and $\mathrm{Pd}_{1.3} \mathrm{Ru}_{1.0} / \mathrm{C}$, due to the smaller amounts of $\mathrm{Pd}$, also showing an intermediate rate of poisoning by $\mathrm{CO}$, suggesting they are viable as catalysts for fuel cells.

\section{Conclusions}

$\mathrm{Pd}_{1.3} \mathrm{Ru}_{1.0} / \mathrm{C}$ shows the best catalytic activity and the lowest propensity for poisoning due to the bifunctional mechanism related to the presence of $\mathrm{RuO}_{2} \cdot \mathrm{Pd}_{3.2} \mathrm{Ru}_{1.3} \mathrm{Mo}_{1.0} / \mathrm{C}$ and $\mathrm{Pd}_{1.5} \mathrm{Ru}_{0.8} \mathrm{Mo}_{1.0} / \mathrm{C}$ show the highest synthesis yields and an intermediate propensity for poisoning compared to $\mathrm{Pd} / \mathrm{C}$ and $\mathrm{Pd}_{1.3} \mathrm{Ru}_{1.0} / \mathrm{C}$, a fact explained by the electronic effect mechanism created by the formation of alloys between the used metals. Due to the lower amount of Pd used in the synthesis of ternary $\mathrm{PdRuMo} / \mathrm{C}$ catalysts and the results presented, we suggest a combination of these three metals supported on Cvulcan as catalyst in alkaline direct ethanol fuel cells.
Table 6 Brief summary of the main characteristics and differences between the catalysts evaluated in this work

\begin{tabular}{llllll}
\hline Catalyst & Alloy formetion & $\begin{array}{l}\text { Oxides } \\
\text { presence }\end{array}$ & Poison onset time & Pd mass & $\begin{array}{l}\text { Coast in } \\
\text { relation to } \\
\text { Pd salt }\end{array}$ \\
\hline $\mathrm{Pd} / \mathrm{C}$ & - & Yes & Low & High & High \\
$\mathrm{Pd}_{1.3} \mathrm{Ru}_{1.0} / \mathrm{C}$ & $\mathrm{No}$ & Yes & High & Average & Average \\
$\mathrm{Pd}_{3.2} \mathrm{Ru}_{1.3} \mathrm{Mo}_{1.0} / \mathrm{C}$ & $\mathrm{Yes}$ & $\mathrm{No}$ & Intermediate & Low & Low \\
$\mathrm{Pd}_{1.5} \mathrm{Ru}_{0.8} \mathrm{Mo}_{1.0} / \mathrm{C}$ & $\mathrm{Yes}$ & $\mathrm{No}$ & Intermediate & Low & Low \\
\hline
\end{tabular}


Supplementary Information The online version contains supplementary material available at https://doi.org/10.1007/s40243-020-00187 -1.Acknowledgements The authors thank the Brazilian agency FAPES (Fundação de Amparo a Pesquisa e Inovação do Espírito Santo) for the financial support by means of grant $n^{\bigcirc} 85201154$ and $n^{\circ} 515 / 2016$. We also thank the laboratories responsible for the characterization of the developed materials: LPT/LMC_-Physics Departament (UFES) for BET Area, Labpetro-Chemistry Departament (UFES) for Raman and XRD measurements (Technical Cooperation agreement). 0050.0022844.06.4 and CT-Infra 01/2007-FINEP 0202/08), Luccar (Morfology Department-CSS/UFES) for SEM/EDX/TEM and Labpol-Dr. Kinglston Soares (CMM/IFES) for TG. Special thanks to Antonio Augusto Lopes Marins (DQUI-UFES) for the suggestions in the discussion of XRD and Raman analyses.

Open Access This article is licensed under a Creative Commons Attribution 4.0 International License, which permits use, sharing, adaptation, distribution and reproduction in any medium or format, as long as you give appropriate credit to the original author(s) and the source, provide a link to the Creative Commons licence, and indicate if changes were made. The images or other third party material in this article are included in the article's Creative Commons licence, unless indicated otherwise in a credit line to the material. If material is not included in the article's Creative Commons licence and your intended use is not permitted by statutory regulation or exceeds the permitted use, you will need to obtain permission directly from the copyright holder. To view a copy of this licence, visit http://creativecommons.org/licenses/by/4.0/.

\section{References}

1. Soloveichik, G.L.: Liquid fuel cells. Beilstein. J. Nanotechnol. 5, 1399-1418 (2014). https://www.beilstein-journals.org/bjnano/ articles $/ 5 / 153$

2. Pedicini, R., Schiavo, B., Rispoli, P., Saccà, A., Carbone, A., Gatto, I., Passalacqua, E.: Progress in polymeric material for hydrogen storage application in middle conditions. Energy $\mathbf{6 4}$, 607-614 (2014) https://ideas.repec.org/a/eee/energy/v64y2014ic p607-614.html

3. Antolini, E.: Structural parameters of supported fuel cell catalysts: The effect of particle size, inter-particle distance and metal loading on catalytic activity and fuel cell. Appl. Catal. B. Environm. 181, 298-313 (2016). https://www.sciencedirect.com/science/artic le/abs/pii/S0926337315300801

4. Torrero, J., Montiel, M., Peña, M.A., Obón, P., Rojas, S.: Insights on the electrooxidation of ethanol with Pd-based catalysts in alkaline electrolyte. Int. J. Hydrogen. Energy. 44, 60, 31995-32002 (2019) https://www.sciencedirect.com/science/article/abs/pii/ S0360319919339357?via\%3Dihub

5. Palma, L.M., Almeida, T.S., Andrade, A.R.: Comparative study of catalyst effect on ethanol electrooxidation in alkaline medium: $\mathrm{Pt}-$ and Pd-based catalysts containing $\mathrm{Sn}$ and Ru. J. Electroanal. Chem. 878, 114592 (2020) https://www.sciencedirect.com/scien ce/article/abs/pii/S1572665720308201?via\%3Dihub

6. Monyoncho, E.A., Woo, T. K., Baranova, E. A.: Ethanol electrooxidation reaction in alkaline media for direct ethanol fuel cells. Electrochemistry 15, 1-57 (2018) https://pubs.rsc.org/en/ content/ebook/978-1-78801-373-4

7. Tran, L.T., Neguen, Q.M., Neguyen, M.O., Le, H.N.T., Neguyen, T.T., Vu, T.H.: Preparation and electrocatalytic characteristics of the Pt-based anode catalysts for ethanol oxidation in acid and alkaline media. Int. J. Hydrogen. Energy. 43, 20563-20572 (2018)
https://www.sciencedirect.com/science/article/abs/pii/S0360 319918328957?via\%3Dihub

8. Dutta, A., Mahapatra, S.S., Datta, J. S. S. S.: High performance PtPdAu nano-catalyst for ethanol oxidation in alkaline media for fuel cell applications. Int. J. Hydrogen Energy. 36, 22 1489814906 (2011). https://www.sciencedirect.com/science/article/ pii/S0360319911004587?casa_token $=$ ZC83spD663UAAAA A:1dGdohPQIEu8BMdxebyMlbD3gIngufV17AZKpuFs_cNiNu gdXSFHRuDK11nJidlb-wz2Ia1oVA

9. Cai, J., Huang, Y., Guo, Y.: Bi-modified Pd/C catalyst via irrervesible adsorption and its catalytic activity for ethanol oxidation in alkaline medium. Electrochimica Acta. v. 99, 22-29 (2013) https://www.sciencedirect.com/science/article/pii/S0013 468613004568

10. Du, W., Mackenzie, K. E, Milano, D.F., Deskins, N.A., Su, D., Teng, X.: Palladium-tin alloyed catalysts for ethanol oxidation reaction in an alkaline medium. ACS Catalysis. 2, 287-297 (2012) https://pubs.acs.org/doi/https://doi.org/10.1021/cs200 5955

11. Oliveira, M., Rego, R., Fernandes, L., Tavares, P.: Evolutions of the cataytic activity of Pd-Ag alloys on ethanol oxidation and oxygen reduction reactions in alkaline medium. J. Power Sourcers. 196, 6092-6098 (2011), https://www.sciencedirect.com/science/ article/abs/pii/S037877531100677X

12. Moraes, L.P.R., Matos, B.R., Radtak, C., Santiago, E.I., Fonseca, F.C., Amico, S.C.,, Malfatti, C.F.: Synthesis and performance of palladium-based electrocatalysts in alkaline direct ethanol fuel cell. Int. J. Hydrogen Energy. 41(15), 6457-6468 (2016) https:// www.sciencedirect.com/science/article/abs/pii/S03603199153117 82

13. Sheikh, S.Y., Silva, E.L., Moraes, L., Antonini, L.M., Abellah, M.Y., Malfatti, C.F.: Pd-based catalysts for ethanol oxidation in alkaline electrolyte. Am. J. Min. Metall. 2, 64-69 (2014) http:// www.sciepub.com/AJMM/abstract/2837

14. Zhao, X., Zhang, J., Wang, L., Liu, Z., Chem, J.: $\mathrm{Pd}_{\mathrm{x}} \mathrm{Cu} 100-\mathrm{x}$ networks: an active and durable electrocatalyst for ethanol oxidation in alkaline medium. J. Mater. Chem. A. 2, 20933-20988 (2014), https://pubs.rsc.org/en/content/articlelanding/2014/ta/c4ta04899g \#!divAbstract

15. Souza, F.M., Bóhnsted, P., Pinheiro, V.S., Oliveira, L.A., Batista, B.L., Parreira, L.S., Antunes, R.A., Santos, M.C.: Niobium increasig the electrocatalytic activity of palladium for alkaline direct ethanol fuel cell. J. Electroanal. Chem. 858, 113824 (2020). https://www.sciencedirect.com/science/article/abs/pii/S1572 665720300072

16. Xu, J.B., Zhao, T.S., Shens, Y., Li, Y.S.: Atomic layer deposition preparation of Pd nanoparticles on a porous carbon support for alcohol oxidation. Int. J. Hydrogen Energy. 35, 6490-6500 (2010) https://www.sciencedirect.com/science/article/abs/pii/ S0360319910006804

17. Chen, Y., Zhuang, L., Lu, J.: Non-Pt anode catalysts for alkaline direct alcohol fuel cells. Chinese J. Catal. 28(10), 870-874 (2007) https://www.sciencedirect.com/science/article/abs/pii/S1872 206707600734

18. Ma, L., He, H., Hsu, A., Chen, R.: PdRu/C catalysts for ethanol oxidation in anion-exchange membrane direct ethanol fuel cells. J. Power Sources. 241, 696-702 (2013) https://www.sciencedirect. com/science/article/abs/pii/S0378775313006496?via\%3Dihub

19. Gomez, J.C.C., Moliner, R., Lázaro, M.J.: Palladium-based catalysts as electrodes for direct methanol fuel cells: a last ten years review. Catalysts. 6(9), 130-138 (2016) https://www.mdpi. com/2073-4344/6/9/130

20. Carrión-Satorre, S., Mantiel, M., Escudero-Cid, R., Fierro, J.1.G., Fatás, E., Ocan, P.: Performance of carbon-supported palladium and palladium-ruthenium catalyts for alkaline membrane direct ethanol fuel cells. Int. J. Hydrogen Energy. 41, 8954-8962 (2016) 
https://www.sciencedirect.com/science/article/abs/pii/S0360 319915313446

21. Fariba, F., Afzali, D.: Bimetallic Pd-Mo nanoalloys supported on Vulcan XC-72R carbon as anode catalysts for direct alcohol fuel cell. Int. J. Hydrogen Energy. 42(5), 3215-3221 (2017) https:// www.sciencedirect.com/science/article/abs/pii/S03603199163287 01

22. Mayalagam, T., Scott, K.: Performance of carbon nanofiber supported Pd-Ni catalysts for electro-oxidation of ethanol in alkaline medium. J. Power Sources. 195(16), 5246-5251 (2010) https:// www.sciencedirect.com/science/article/abs/pii/S03787753100041 2X?via\%3Dihub

23. Elezovic, N.R., Zabinskib, P., Ercius, P., Wytrwal, M., Radmilovic, V.R., Lacnjevac, U.C., Krstajicd, N.V.: High surface area $\mathrm{Pd}$ nanocatalyst on core-shell tungsten based support as a beneficial catalyst for low temperature fuel cells application. Electrochim. Acta 247, 674-684 (2017). https://doi.org/10.1016/j.elect acta.2017.07.066

24. Wen, C., Wei, Y., Tang, D., Sa, B., Zhang, T., Changxin Chen, C.: Improving the electrocatalytic properties of Pd-based catalyst for direct alcohol fuel cells: effect of solid solution. Scient. Rep. 7: 4907(2017) https://ui.adsabs.harvard.edu/abs/2017N atSR...7.4907W/abstract

25. Iwasita, T.: Electrocatalysis of methanol oxidation. Electrochimica Acta. 47, 22-23, 3663-3674 (2002). https://www.sciencedirect. com/science/article/pii/S0013468602003365

26. Christensen, P.A., Hamnett, A., Troughton, G.L.: The role of morphology in the methanol electro-oxidation reaction. J. Electroanal. Chem. 362(1-2), 207-218 (1993), https://www.sciencedirect.com/ science/article/abs/pii/002207289380023B

27. Marković, N. M., Gasteiger, H. A., Ross, P. N., Jiang, X., Weaver, M. J.: Electro-oxidation mechanisms of methanol and formic acid on Pt-Ru alloy surfaces. Electrochemistry Acta. 40(1), 91-98 (1995) https://www.sciencedirect.com/science/article/pii/00134 $6869400241 \mathrm{R}$

28. Gojković, S.L., Vidaković, T.R., Đurović, D.R.: Kinetic study of methanol oxidation on carbon-supported PtRu electrocatalyst. Electrochimica Acta. 48(24), 3607-3614 (2003) https://www. sciencedirect.com/science/article/pii/S001346860300481X

29. Tayal, J., Rawat, B., Basu, S.: Bi-metallic and tri-metallic Pt$\mathrm{Sn} / \mathrm{C}, \mathrm{Pt}-\mathrm{Ir} / \mathrm{C}, \mathrm{Pt}-\mathrm{Ir}-\mathrm{Sn} / \mathrm{C}$ catalysts for electro-oxidation of ethanol in direct ethanol fuel cell. Int. J. Hydrogen Energy. 36(2), 14884-14897 (2011), https://www.sciencedirect.com/science/artic le/abs/pii/S0360319911006240

30. Zu, M., Sun, G., Li, H., Cao, L., Xin, Q.: Effect of the Sn(II)/ $\mathrm{Sn}(\mathrm{IV})$ redox couple on the activity of $\mathrm{PtSn} / \mathrm{C}$ for ethanol electrooxidation, Chinese. J. Catal. 29(8), 765-760 (2008) https://www. sciencedirect.com/science/article/abs/pii/S1872206708600674

31. Petrii, O.A.: Pt-Ru electrocatalysts for fuel cells: a representative review. J. Solid State Electrochem. 12, 604-642 (2008) https://link.springer.com/article/https://doi.org/10.1007/s1000 8-007-0500-4

32. Gong, L., Yang, Z., Li, K., Xing, W., Liu, C., Gea, J.: Recent development of methanol electrooxidation catalysts for direct methanol fuel cell. J. Energy Chem. 27, 1618-1628 (2018) https ://www.sciencedirect.com/science/article/abs/pii/S209549561 7310380?via\%3Dihub

33. Robinson, A., Ferguson, G.A, Gallagher, J.R., Cheah, S., Beckham, G,T. , Schaidle, J.A, Hensley, J.E, Medlin. J.W.: Enhanced hydrodeoxygenation of $m$-Cresol over Bimetallic Pt-Mo catalysts through an oxophilic metal-induced tautomerization pathway. ACS Catal. 6, 64356-4368 (2016) https://pubs-acs-org.ez43. periodicos.capes.gov.br/doi/abs/https://doi.org/10.1021/acsca tal.6b01131
34. Queiroz, M.A.R., Ribeiro, J.: Catalysts of PtSn/C Modified with $\mathrm{Ru}$ and Ta for Electrooxidation of Ethanol. Catalysts. 9(3), 277 (2019). https://doi.org/10.3390/catal9030277

35. Pillai, S. R., Sonawane, S. H., Gumfekar, S. P., Suryawanshi, P. L., Ashokkumar, M., Potoroko, I.: Continuous flow synthesis of nanostructured bimetallic Pt-Mo/C catalysts in milli- channel reactor for PEM fuel cell application. Mater. Chem. Phys. 237, 121854 (2019) https://www.sciencedirect.com/science/article/abs/ pii/S0254058419306510?via\%3Dihb

36. Cullity, B. D.: Elements of X-Ray Diffraction, $2^{\text {nd }}$ Ediction, Addison-Wesley Publishing Company, USA (1978) https://books .google.com.br/books/about/Elements_of_X_ray_Diffractio n.html?id=WpxpAAAAMAAJ\&redir_esc $=$ y

37. Knupp, S.L., Vukmirovic, M.B., Haldar, P., Herron, J.A, Mavrikakis, M., Adzic, R. R.: Platinum Monolayer Electrocatalysts for $\mathrm{O}_{2}$ Reduction: Pt Monolayer on Carbon-Supported PdIr Nanoparticles. Electrocatalysis. 1, 213-223 (2010) https://link.springer. com/article/https://doi.org/10.1007/s12678-010-0028-8

38. Fisher, J.M.; Cabello, N.M.; Christian, E.; Thompsett, D.: Methanol oxidation activity of PdRu alloy nanoparticles in direct methanol fuel cells. Electrochem. Solid-State Lett. 12(5), 77-81, (2009) https://iopscience.iop.org/article/https://doi.org/10.1149/1.30956 75/meta?casa_token=AJaaRtZ_FuAAAAAA:SrGZMbuugTbA5 Qg8MBzPuYzkuvxUTzwo4Fknhk890hireeaWuQNvcLoHb1 JBboHYyPp6PufpUB61A

39. Monyoncho, E.A. , Ntais, S., Soares, F., Woo, T.K., . Baranova, E.A.: Synergetic efefect of palladium-ruthenium nanostructures for ethanol electrooxidation in alcaline media. J. Power Sources. 287, 139-149, (2015), https://www.cheric.org/research/tech/perio dicals/view.php?seq=1391486

40. He, Q., Chen, W., Mukerjee, S., Chen, S., laufek, F.: Carbonsupported $\mathrm{PdM}(\mathrm{M}=\mathrm{Au}$ and $\mathrm{Sn})$ nanocatalysts for the electrooxidation of ethanol in high pH media. J. Power Sources 187(2), 298-304, (2009) https://www.sciencedirect.com/science/article/ abs/pii/S0378775308021800

41. Mukundan, V., Yin, J., Joseph, P., Luo, J., Shan, S., Zakharov, D.N., Zhong, C.J., Malis, C.: Nanoalloying and phase transformations during thermal treatment of physical mixtures of $\mathrm{Pd}$ and $\mathrm{Cu}$ nanoparticles. Sci. Technol. Adv. Mater. 15, 2 (2014). https://doi. org/10.1088/1468-6996/15/2/025002

42. ASM-International. ASM handbook. In: Alloy phase diagrams, vol. 03. ASM International; (1992) https://www.asminternationa 1.org/bestsellers/-/journal_content/56/10192/25871543/PUBLI CATION

43. McBride, J. R., Hass, K. C., Weber, W.H.: Resonance-Raman and lattice-dynamics studies of single-crystal PdO. Phys. Rev. B. 44(10), 5016-5028 (1991), https://journals.aps.org/prb/ abstract/https://doi.org/10.1103/PhysRevB.44.5016.

44. Zhao, Z., Elwood, J., Carpenter, M.A.: Phonon Anharmonicity of PdO Studied by Raman Spectrometry. J. Phys. Chem. C. 119, 23094-23102 (2015), https://pubs.acs.org/doi/abs/https:// doi.org/10.1021/acs.jpcc.5b07652?casa_token=RpM5_kmYZ4 sAAAAA:2h 72fxTmNmTU6RIJopLfoH_q-kDWLMhVna_3dB BtMiDKOSyLT5XQO4aVQTIKKueAAXkG-J5L0oSUZLA

45. Shin, H.Y., Lee, J., Lee, Y., Jeong, S., Jung, H., Yu, H.K., Baik, J.M., . Kim, Yoon, S.: Probing the Growth Habit of Highly Single Crystalline Twinned V-Shape $\mathrm{RuO}_{2}$ Nanowires by Polarized Raman Scattering. J. Phys. Chem. C. 118, 20716-20720 (2014) https://pubs.acs.org/doi/abs/https://doi.org/10.1021/jp506 9208? casa_token=aa26YJPJL7oAAAAA:Jg_UuNVRpWRTe o3DtX7OS8Z-gb7b4wGoe_UxD58Ogsf8ju96o3DUSVXnMAN tk6VxS-Sl3IfmTsFAoio

46. Meng, L.J., Teixeira, V., Santos, M.: Raman spectroscopy analysis of magnetron sputtered $\mathrm{RuO}_{2}$ thin films. Thin Solid Films. 442, 93-97 (2003) https://linkinghub.elsevier.com/retrieve/pii/S0040 609003009532

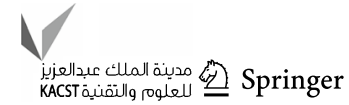


47. Pradhan, B.K., Sandle, N.K.: Chemistry and kinetics of chemical vapor infiltration of pyrocarbon - VI. Mechanical and structural properties of infiltrated carbon fiber felt. Carbon. 37(8), 13231332 (1999), https://www.sciencedirect.com/science/article/abs/ pii/S0008622398003273

48. Figueiredo, J., Pereira, M.F., Órfão, J.J.: Modification of the surface chemistry of activated carbons. Carbon. 37(9), 1379-1389 (1999) http://dns2.asia.edu.tw/ ysho/YSHO-Engli sh/1000\%20WC/PDF/Carbon37,\%201379.pdf

49. Hammed, R. M. A.: Enhanced ethanol electrooxidation reaction on carbono supported Pd-metal oxide electrocatalyst. J. Colloid Interface Sci. 505, 230-240 (2017) https://www.sciencedirect. com/science/article/abs/pii/S0021979717306239

50. Zhu, C., Wen, D., Oschatz, M., Halzchuh, M., Liu, W., Herrmann, A. K., Simon, F., Kaskel, S., Eychmüller, A.: Kinectically controlled synthesis of pdni bimetallic porous nanostrucures with enhanced electrocatalytic activity. Small 11(12), 1430-1434 (2015). https://onlinelibrary.wiley.com/doi/abs/https://doi. org/10.1002/smll.201401432

51. https://www.merckmillipore.com/Web-BR-Site/pt_BR/-/BRL/ ViewUserAccount ShowLogin?TargetPipeline=ViewProductStart\&RedirectQueryString=SKU\%3DMDA_CHEM 814573 accessed in August 30, 2020

52. Pattabiraman, R.: Electrochemical investigations on carbon supported palladium catalysts. Appl. Calaly. A. General. 153, 9-20 (1997) https://www.sciencedirect.com/science/article/abs/pii/ S0926860X96003274
53. Farjado, H.V., Longo, E., .Leite, E.R., LibaroniII, L., Probst, L.F.D., Carreño, N.L.V.: Synthesis, characterization and catalytic properties of nanocrystaline $\mathrm{Y}_{2} \mathrm{O}_{3}$-coated $\mathrm{TiO}_{2}$ in the ethanol dehydration reaction. Mater. Res. Bull 15(2) (2012) https://www. scielo.br/pdf/mr/v15n2/aop_0964-11.pdf

54. Liang, X.; Zhao, T.S.; Xu, J.B.; Zhu, L.D.: "Mechanism study of the ethanol oxidation reaction on palladium in alkaline media". Electrochimica Acta. 54(8), 2203-2208 (2009) https://www-scien cedirect.ez43.periodicos.capes.gov.br/science/article/pii/S0013 468608012395

55. Geraldes, A.N.; Fortunato, D.S.; Martins, J. C.; Sá, O.A.; Spinacé, V.; Oliveira Neto, A.; Santos, M.C.: Palladium and palladium-tin supported on multi wall carbon nanotubes or carbon for alkaline direct ethanol fuel cell. J. Power Sources 275 (2015) 189-199 https://www.sciencedirect.com/science/article/abs/pii/S0378 775314018503

56. Baylet, A., Marecot, P. Duprez, D, Castellazzi, P., Groppi, G., Forzatti, P.: In situ Raman and in situ XRD analysis of PdO reduction and $\mathrm{Pd}$ oxidation supported on $\mathrm{Al}_{2} \mathrm{O}_{3}$ catalyst under different atmospheres. Phys. Chem. Chem. Phys. 13, 4607-4613 (2011) https://pubs.rsc.org/en/content/articlelanding/2011/cp/c0cp0 1331e\#!divAbstract

Publisher's Note Springer Nature remains neutral with regard to jurisdictional claims in published maps and institutional affiliations.

\section{Authors and Affiliations}

\section{Yonis Fornazier Filho ${ }^{1}$ - Ana Caroliny Carvalho da Cruz $^{1} \cdot$ Rolando Pedicini $^{2}$. José Ricardo Cezar Salgado ${ }^{3}$. Priscilla Paiva Luz ${ }^{1} \cdot$ Josimar Ribeiro $^{1}$ (])}

Josimar Ribeiro

josimar.ribeiro@ufes.br

Yonis Fornazier Filho

yonis.fornazier@gmail.com

1 Departamento de Química-Centro de Ciências Exatas, Universidade Federal Do Espírito Santo (UFES), Avenida Fernando Ferrari, Goiabeiras 514, Vitória, ES 29075-910, Brazil
2 Istituto Di Tecnologia Avanzate Per L'Energia "Nicola Giordano" (ITAE) - Via S. Lucia Sopra Contesse, 5-98126 Messina, Italy

3 Universidade Federal da Integração Latino-Americana (UNILA), Instituto Latino-Americano de Ciências da Vida E da Natureza, Avenida Silvio Américo Sadelli, Foz do Iguaçu-PR 1842, 85866-000, Brazil 